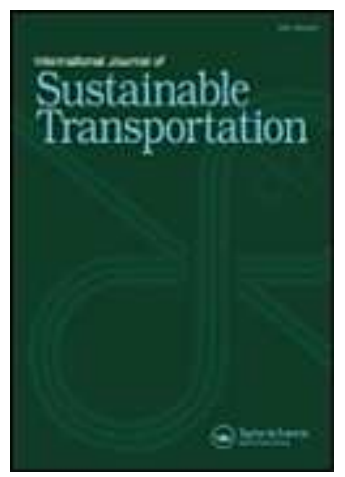

\title{
Energy Saving Obligations and White Certificates: Ideas and Considerations for the Transport Sector
}

\begin{tabular}{|r|l|}
\hline Journal: & International Journal of Sustainable Transportation \\
\hline Manuscript ID: & UJST-2009-0046.R1 \\
\hline Manuscript Type: & Full Paper \\
\hline Date Submitted by the & $\mathrm{n} / \mathrm{a}$ \\
\hline Complete List of Authors: & $\begin{array}{l}\text { Bertoldi, Paolo; European Commission, Joint Research Centre, } \\
\text { Institute for Energy } \\
\text { Rezessy, Silvia; European Commission, Joint Research Centre, } \\
\text { Institute for Energy } \\
\text { Anable, Jillian; Centre for Transport Research, University of } \\
\text { Aberdeen } \\
\text { Jochem, Patrick; Karlsruhe Institute of Technology, Institute for } \\
\text { Industrial Production } \\
\text { Oikonomou, Vlasis; Joint Implementation Network }\end{array}$ \\
\hline Keywords: & energy, saving, obligations, white, certificates, transport \\
\hline
\end{tabular}

\section{今scholaroNE" \\ Manuscript Central}




\section{Energy Saving Obligations and White Certificates:}

\section{Ideas and Considerations for the Transport Sector}

Paolo Bertoldi

European Commission, DG JRC, Institute for Energy

I-21020 ISPRA (VA), Italy

Email: paolo.bertoldi@ec.europa.eu

10

Silvia Rezessy

European Commission, DG JRC, Institute for Energy

I-21020 ISPRA (VA), Italy

Email: silvia.rezessy@ec.europa.eu

15

Jillian Anable

Senior Lecturer, Centre for Transport Research,

University of Aberdeen

Email: j.anable@abdn.ac.uk

Patrick Jochem

Institute for Industrial Production at Karlsruhe Institute of Technology

D-76187 Karlsruhe, Germany

Email: jochem@kit.edu

Vlasis Oikonomou

Joint Implementation Network (NL)

Groningen, the Netherlands

Email: vlasis@jiqweb.org 
Energy saving obligations and white certificates in transport

\title{
Keywords
}

Energy efficiency, savings obligations, white certificates, transport

\begin{abstract}
$^{1}$
5 A lot of policy interest and analysis has been focused on energy saving obligations on energy distributors or suppliers (mainly electricity and gas) coupled with trading of certified energy savings via tradable white certificates. While in the European Union the Energy Services Directive (2006/32/EC) also applies to transport fuels and some of the existing energy saving obligations allow certification of savings from transport projects, as of end of 2009 no EU Member State has energy saving obligations on transport fuel distributors.

10 The paper explores the application of energy saving obligations in road transport, discussing the imposition of energy saving obligations on transport fuel suppliers, the definition of eligible technologies and projects, and considering energy saving obligations as a stand-alone tool or integrated with existing electricity and gas obligations. The paper intends to open further discussion and research on the topic.
\end{abstract}

\footnotetext{
${ }^{1}$ The authors thank Sibyl Steuwer for helpful comments.
} 


\section{Introduction}

Transport is a key sector in the environmental and energy security contexts. Member states of the European Union are highly dependent on imported transport fuels - in 2005 the oil dependency of the 27 member states of the European Union (EU-27) was $82.3 \%$ with more than two thirds of imports coming from the Middle East and

Russia (EC 2008). In the EU-27 transport is the second largest emitter of greenhouse gases (GHG) after the energy generation sector (Eurostat 2008). ${ }^{2}$

In terms of Kyoto commitments, in 2007 total GHG emissions in EU-27 were 12.5\% below base year (1990) levels $^{3}$ and 1.2\% lower compared to 2006 (EC 2009). Between 2006 and 2007 emissions in the EU-27 fell, with a slight increase in New Member States ${ }^{4}$. The sectors that have already made major contributions to the Kyoto 0 GHG emission target include industrial processes (-11\%), energy generation, transformation, supply and use ($7 \%$ ), as well as agriculture and waste (-11\% and $-39 \%$ respectively) (EC 2009).

One notable exception is the transport sector, whose GHG emissions increased by 24\% between 1990 and 2007. Overall, the share of transport in total GHG emissions in the EU was $21 \%$ in 2007 not including aviation and shipping movements outside individual national borders which would increase this total by 30\% (EC 2009).

15 When considering only transport within European borders, the share of road transport exceeds $90 \%$ of the direct transport emissions (Eurostat 2009). Emissions from road transport have continued to grow in most countries due to growth in traffic volumes, increasing by $1 \%$ in the EU-27 between 2006 and 2007 alone.

Recent trends in $\mathrm{CO}_{2}$ emissions from transport are also expected to continue. The JRC estimates that GHG between 2000 and 2050 emissions from domestic transport in the EU-27 will increase by 24\%, during which 20 time emissions from road transport are projected to increase by 19\% (JRC 2008). On the basis of these trends and expectations about the rate of technological and behavioural change, many studies have concluded that transport will be among the last sectors to bring its emissions down below current levels (Stern 2007, Annex 7c). Indeed a review of $20 \mathrm{EU}$-wide and global scenario exercises concluded that total reduction potential of the sector by 2050 is generally less than 50\% from 1990 levels, with the major share generally expected to come from technical solutions (Skinner et al. 2010). Other studies have disputed this finding by demonstrating how the combination of demand and supply side approaches and the adoption of small scale 'soft' measures are cost-

\footnotetext{
${ }^{2}$ Besides GHG emissions the transport sector emits carbon monoxide, nitrogen oxides, volatile organic compounds and other particles which are hazardous for human health and the environment. These are not covered by this article.

${ }^{3}$ Without emissions and removals from Land Use, Land Use Change and Forestry (LULUCF).

${ }^{4}$ Mostly post-communist countries in Central and Eastern Europe that joined the EU in 2004 and 2007.
} 


\section{Energy saving obligations and white certificates in transport}

effective routes to demand reduction in this sector (CfIT 2007; Anable 2008). However, almost all studies conclude that the sector needs to adopt all the solutions at its disposal and more, both behavioral and technical, 'hard' and 'soft', if the transport sector is to avoid being responsible for jeopardizing EU emission reduction targets.

5 Since it is unlikely that transport agents will reduce their energy consumption and $\mathrm{CO}_{2}$ emissions voluntarily, policy interventions are necessary to ensure that the transport sector contributes to national and international emission targets. High emission reduction potentials exist in the transport sector, especially in road transport, through smaller and more fuel efficient vehicles and modal shift (BMU 2006, Schäfer 2000, and DeCicco and Ross 1996). In Germany emission reductions of about $14 \mathrm{Mt} \mathrm{CO}_{2 \mathrm{e}}$ can be achieved cost effectively in the road transport sector (BDI 2007).

\subsection{Policy instruments targeting greenhouse gas emissions and energy use reductions in the transport sector}

Sustainable transport policies in Europe have traditionally been focused on regulations (standards), transportation pricing reform (e.g. fuel taxes, annual motor vehicle taxes, parking pricing, incentives to purchase

15 fuel efficient vehicles), carbon taxes, information tools, voluntary actions, improving travel options, increasing the demand of alternative fuels, influencing modal split, as well as urban and land-planning strategies and traffic management systems. Whilst around $40 \%$ of Europe's GHG emissions are covered by the Emissions Trading Scheme (ETS), the transport sector, with the exception of aviation from 2012, remains outside of the ETS.

Information tools, such as labeling and databases, support the user in making informed choices that have 20 implications on the lifecycle costs of acquiring, owning and operating a vehicle. Fiscal and economic policies include charges, taxes and financial support. Energy taxation 'punishes' consumption (and thus inefficiency and excessive usage), while fiscal tools and financial support (e.g. investment grants, accelerated depreciation, etc.) may be designed to improve the economics of technological solutions that may have higher upfront costs even if their lifecycle costs are lower. Infrastructure policies provide priority for efficient transport modes in the 25 infrastructure (modal shift via the provision of cycle lanes, bus priority lanes, improved public transport services and road space relocation, modal shift from road to rail in freight transport, parking policies). Spatial planning takes long-term effects in the transport system into account and gives instructions to the urban developers to optimize the regional transport system (with respect to public transport, urban densification, and car sharing etc.). Traffic and mobility management consider the middle-term perspective and optimize the utilization of the 
Energy saving obligations and white certificates in transport

existing infrastructure by introducing GPS optimized congestion bypassing, optimized traffic routing, the provision of cycle lanes, bus priority lanes, improved bus services, road space reallocation, parking policies, and soft measures such as car sharing, information provision and travel planning. Voluntary action introduces voluntary commitments by market actors (e.g. car manufacturers) (UKERC 2007; UBA 2007 and 2008; CE

5 Delft 2006). In the authors' view cap-and-trade programs appear to be a very complex option for road transport because covering a huge number of transport operators would impose huge administrative burden. Other authors - such as Raux (2010) - have put forward proposals for tradable rights for fuel consumption for personal travel, while acknowledging that these would involve high costs of implementation given the very large number of actors concerned.

10 In the last decade informational and voluntary instruments for transport sustainability are gaining importance: these instruments are suggested in the "Three Pillar Approach", the first strategy of the European Commission to reduce $\mathrm{CO}_{2}$ emissions in passenger road transport (EC 1995). The European Automobile Manufacturers Association (ACEA) made a voluntary commitment to reduce the average $\mathrm{CO}_{2}$ emissions to 140 grams of $\mathrm{CO}_{2}$ per kilometer driven $\left(\mathrm{g} \mathrm{CO}_{2} / \mathrm{km}\right)$ for new cars by 2008. Similar voluntary commitments were also made by 15 Japanese and Korean car manufacturers. However, the voluntary target was not reached and in 2008 average emissions for new cars were significantly above target at $154 \mathrm{~g} \mathrm{CO} / \mathrm{km}$ helped by the largest single annual reduction in the final year due to the recession and high fuel prices (T\&E 2009). In December 2008, the Council of Ministers and the European Parliament agreed to impose the $130 \mathrm{CO}_{2} \mathrm{~g} / \mathrm{km}$ limit on $65 \%$ of the new car fleet from 2012, 75\% from 2013, 80\% from 2014 and all by 2015, with another 10 grams of $\mathrm{CO}_{2}$ to be saved with 20 "eco-measures". A longer-term target of $95 \mathrm{~g} \mathrm{CO}_{2} \mathrm{~g} / \mathrm{km}$ is set for 2020 . Manufacturers may obtain a maximum additional emission credit of $7 \mathrm{CO}_{2} \mathrm{~g} / \mathrm{km}$ if vehicles are equipped with innovative carbon reducing technologies and this is independently verified; these should be over and above any changes designed to secure an additional 10g reduction as part of the integrated approach. Penalty payments will apply from 2012 to 2018 of 5 Euro for the first $\mathrm{g} / \mathrm{km}, 15$ Euro for the second $\mathrm{g} / \mathrm{km}, 25$ Euro for the third and for each additional $\mathrm{g} / \mathrm{km}$ over the limit, 25 and 95 Euro for each subsequent g/km, per vehicle sold. From 2019 the penalty will be 95 Euro per g/km. These targets are now mandatory: the legislation on $\mathrm{CO}_{2}$ from passenger cars is now officially published in the form of Regulation (EC) No 443/2009 of the European Parliament and of the Council of 23 April 2009 setting emission performance standards for new passenger cars as part of the Community's integrated approach to reduce $\mathrm{CO}_{2}$ emissions from light-duty vehicles (OJ 2009).

30 Given the transport emission trends indicated above, existing policies have been only partially successful. While a demand shift to smaller and more efficient cars has been seen, reduced consumption per km - respectively 
Energy saving obligations and white certificates in transport

reduced per-km vehicle operating costs - has been associated with a rebound effect of increased vehicle use thus requiring additional measures to effectively maintain real travel costs (Frondel et al. 2007). Goodwin et al. (2004) argue that the price-elasticity of total transport demand is negative, at about -0.6 in the long term, whereas the income-elasticity of transport fuel demand is much stronger with a positive value of about 1.2.

5 Consequently transport pricing policies and carbon taxation may require a much faster increase in the cost of transport than in income, which has not been the effect of fuel taxation and carbon taxation policies to date.

Transport is a complex sector with a huge number of stakeholders and delivery channels involved. Hence, no policy instrument alone can ensure a significant and sustained effect - a balanced mix of instruments is needed to ensure the desired response, combining technological solutions and a rethink of demand (UKERC 2007; UBA 102007 and 2008; CE Delft 2006).

In this paper, we explore the introduction of energy saving obligations on transport fuel suppliers, following the logic of energy saving obligations on electricity and gas suppliers. Under existing energy saving obligations introduced in a number of EU countries (see the discussion in this paper), energy distributors or suppliers mostly suppliers of network-bound energies, such as electricity and gas - have to implement energy efficiency 15 projects at the premises of end-users or purchase certified energy savings from other parties implementing projects in order to meet energy savings targets. While the Energy Services Directive (Directive 2006/32/EC) applies to transport fuels too, as of late 2009, no EU country had an energy saving obligation on transport fuel distributors or suppliers. To the best knowledge of the authors, this option has not been discussed in policy research literature. However, as of early 2010 there are indications that France will be integrating transport 20 saving obligations into its comprehensive system of energy saving obligations targeting energy suppliers.

In this paper we first outline the principles of energy saving obligations, particularly white certificate schemes, as they exist in different EU member states, providing a brief comparative analysis of these. Bertoldi et al (2010) offers a comprehensive comparative analysis of the topic. Subsequently, in this paper we discuss the potential application of energy saving obligations and white certificates to the transport sector. Acknowledging that sustainable transport policies need to tackle complex relationships, we intend to open a discussion as to the potential role of energy saving obligations in delivering energy savings and thus emission reductions. This is in the context of Directive 2006/32/EC and the 2020 climate and energy policy targets endorsed by EU Heads of State and Government in March 2007. The paper does not go into a detailed comparative analysis of savings obligations and tradable certificates in transport with other tools. 
Energy saving obligations and white certificates in transport

The starting premises of the paper is that the potential attractiveness of such schemes in transport may come from their ability to circumvent problems of low price elasticity and high income elasticity of transport (which undermine fiscal tools, such as taxation), while at the same time ensuring a certain outcome (unlike information and education, or purely voluntary undertakings), establishing a financing channel to pay for

5 energy saving interventions and providing for flexibility in complying with the targets. Energy saving obligations have successfully delivered savings targeting distributors or suppliers of electricity, natural gas, district heating and heating oil. Placing transport fuel suppliers under such obligations appears to be a logical continuation of this policy trend. As already indicated, as of late 2009 the French authorities are discussing the extension of the existing energy saving obligation to cover transport fuel suppliers too.

10 An important clarification is needed at this point. Other authors have looked at capping emissions from transport (e.g. Raux and Marlot 2004 for the case of domestic motor vehicle fuel consumption, Raux 2010 for domestic tradable fuel rights, or Jochem 2009 for emission trading scheme in transport). In contrast, this paper examines the case of energy saving obligations coupled with certification of energy savings from technical and behavioral projects under a baseline-and-credit system. In the authors' view a stand-alone cap-and-trade systems for the

15 transport sector are not applicable due to the large number of potential stakeholders involved, which is expected to increase the administrative costs. Nevertheless, the paper does draw on research findings on capping transport emissions, which are relevant for the present work (for example in the context of the level for imposing savings targets).

The structure of the paper is as follows. In section 2 we present a comparative review of the characteristics of energy saving obligations and Tradable White Certificate (TWC) schemes in Europe, pointing to the implications of certain design choices. The descriptive review in sub-sections 2.1 to 2.3 is followed by a summary and analysis in sub-section 2.4. Section 3 introduces the authors' view on the possible modalities of energy saving obligations and TWC schemes in the transport sector and provides several design options. In Section 4 we discuss the advantages and drawbacks of the scheme. Section 5 concludes.

\section{White Certificate schemes: application fields in Europe}

In the emission reduction context, cap-and-trade schemes have been widely discussed in many contexts and implemented in many countries. Under a cap-and-trade approach an aggregate cap on emissions is apportioned among individual parties covered in the form of emission permits. Emissions permits are either auctioned or 


\section{Energy saving obligations and white certificates in transport}

given away for free based on different criteria. Emitters under the cap are allowed trade emission allowances among each other. In theory this allows them to achieve their individual caps in the most cost efficient manner.

In contrast, a baseline-and-credit scheme refers to obtaining credits for project activities due to which the emissions or, as discussed in this paper, the energy use of a party are taken below their baselines. Energy saving obligations (targets), also known as supplier or utility obligations, and white certificate schemes are a form of baseline-and-credit system, whereby specific energy saving targets are set for some category of energy market operators, such as energy distributors, suppliers, or even consumers. These operators must fulfill the targets by implementing energy efficiency and energy savings measures among end-users within a specific time frame. The fulfillment is acknowledged by means of TWCs verified by an independent party. Directive 10 2006/32/EC defines white certificates as: "certificates issued by independent certifying bodies confirming the claims of market actors for savings of energy, as a consequence of energy end- use efficiency measures."

The philosophy underlying this system is to combine the guaranteed results of setting obligations with the economic efficiency of market-based mechanisms. Those market actors who receive obligations (savings targets) can decide whether to implement energy efficiency measures directly, via daughter companies or via

15 partnerships with third parties, or to purchase TWCs, or to pay non-compliance penalties, depending on their marginal costs of compliance. Those operators, who can tap a low cost potential and exceed their targets, can sell their TWCs to market actors under savings obligations who have delivered project savings below their target obligation. In this way, TWCs ensure high flexibility and thus contribute to the implementation of measures that are more cost-effective. Under certain conditions, other economic actors without obligations - such as energy service companies (ESCOs) - can certify savings from projects they implement and sell TWCs to energy market actors under obligation.

In the European Union energy savings obligations imposed on different categories of energy market actors exist in the UK ${ }^{5}$, Italy, France, Denmark, and the Flemish region in Belgium. Italy and France have energy savings obligations in combination with TWCs ${ }^{6}$. Obligations or projects can be traded without formal certification in the 25 UK and Denmark. In its National Energy Efficiency Action Plan (NEEAP) under Directive 2006/32/EC Poland declared its intention to introduce a white certificate scheme from 2009; as of October 2009 preparatory work on the design of the scheme has advanced, but no legislation has been adopted. The Irish government is to go for public consultation on its "Energy Demand Reduction Target" program, which may involve supplier saving

\footnotetext{
${ }^{5}$ The scheme only covers Great Britain.

${ }^{6}$ In Italy certificates are called Energy Efficiency Titles. In France they are referred to as Certificates of Energy Savings.
} 
obligations ${ }^{7}$. These schemes have been extensively analyzed (see, for example, Pavan 2008; DEFRA 2007; Monjon 2006; Bertoldi and Rezessy 2006; Bertoldi and Rezessy, 2008; Bertoldi et al. 2009; D’haeseleer et al. 2007). Outside Europe, TWC schemes have been introduced in Australia (New South Wales, see Passey et al. 2008). A number of states in the United States have policies that create long-term energy efficiency obligations;

5 out of these five states have $\mathrm{TWCs}^{8}$, but only in Connecticut are TWCs being actively traded for compliance purposes (Friedman et al. 2008).

So far, energy saving obligations and TWC schemes have not been applied explicitly to the transport sector: while energy savings from transport projects are eligible for certification both in France and in Italy, no transport fuel supplier has been formally placed under an energy saving obligation as of late $2009^{9}$. France announced that in the second phase of it scheme (2010-2013) the energy saving obligation would cover also the transport fuel suppliers. At the time of submission of the final version of this paper (June 2010) the second phase obligations have not been formally legislated.

A number of key design elements need to be examined in order to understand the potential for the application of energy saving obligations and TWC in the transport sector, to assess design options and to point to some of the complexities involved in the transport sector application. In the following paragraphs we outline how these elements are currently resolved in the gas and electricity supplier obligations schemes and tradable certificate markets before looking in Section 3 at the possible design of energy saving obligations in the transport sector.

\subsection{Size, unit and temporal content of the obligation}

Energy savings may embody different commodities, such as primary energy, final energy or $\mathrm{CO}_{2}$ content of energy saved. Some Member States have expressed the obligations in primary energy (Italy and Flanders region in Belgium) and some have expressed them in final energy (Denmark and France). The target under the ongoing phase of supplier obligation in the UK (CERT) is expressed in $\mathrm{CO}_{2}$; previously it was expressed in final energy, standardized to take into consideration the carbon content of fuels saved ${ }^{10}$.

The choice of unit of obligation ultimately depends on the main policy goal under which an obligation is 25 introduced (security of supply, reliability of supply, etc.). Setting targets in terms of $\mathrm{CO}_{2}$ reduction may

\footnotetext{
${ }^{7}$ In addition, in Ireland the Electricity Supply Boards (ESB) each year agrees on an energy efficiency program the Commission on Energy Regulation (CER). Targets are set for savings in energy use which can be achieved though promotion of energy efficient products and education of customers on energy efficient practices.

${ }^{8}$ In the United States white certificates are referred to as energy efficiency certificates or credits, white certificates or tradable white certificates, or white tags. In individual markets the titles are based on specific policy language, such as Class III Renewable Energy Credits (Connecticut), Portfolio Energy Credits (Nevada), Tier II Alternative Energy Credits (Pennsylvania).

9 Saving obligation should not be confused with a renewable fuel obligation, such as the biofuel sales requirement.

${ }^{10}$ The fuel-standardisation is devised to ensure that the target units are directly related to the carbon emissions saved, irrespective of the fuel(s) concerned.
} 


\section{Energy saving obligations and white certificates in transport}

complement the EU Emission Trading Scheme (ETS) by covering sectors that are outside the ETS and whose inclusion is not considered appropriate for the time being (e.g. the residential sector) ${ }^{11}$. On the other hand $\mathrm{CO}_{2}$ reduction is not the only benefit of end-use energy efficiency.

Whether to set a target in primary or final energy is a national choice, among others related to the decision whether and under what conditions to credit supply side solutions, such as cogeneration or small-scale renewables. As a consequence, a target expressed in primary energy gives a strong bias towards electricity savings.

The definition of compliance period (temporal content of the target) and the rate of increase are defined explicitly to provide a confident planning reliability for the obligated parties and their stakeholders. Some

10 Member States have fixed multi-annual targets and compliance is to be demonstrated at the end of the period (UK and France), while others have annual targets and annual compliance (Denmark, Italy and Flanders). To ensure policy stability in Denmark, Italy and Flanders annual targets are established in the framework of a multiannual period of obligations. In the case of multi-annual targets obligation periods last 3 years on average. This relatively short obligation period allows adjustments of the targets or the operational modalities of the scheme.

15 At the same time investment stability is ensured whereby short obligations periods are combined with a longterm policy commitment, long lifetimes of measures and certificate validity and banking of measures or savings for use in future periods. In addition, in the UK, obliged companies must report on annual progress even if they have to only demonstrate compliance at the end of the period. Annual targets give the system administrator the possibility to correct for any implementation flaws.

20 The UK and France express their targets in cumulative terms, i.e. in the final year of the period. Italy has progressively increasing annual targets for electricity and gas distributors by 2012. In Italy projects contribute towards the achievement of the target for 5 years only (in some exceptional case 8 years) and there is no discounting of the savings over this lifetime. In the UK and France the technical lifetimes of measures are used in calculating lifetime savings: in the UK, for example, technical lifetimes range between 8 and 40 years. In 25 Denmark and Flanders only first year savings count towards the target, i.e. the implicit lifetime of a measure is only 1 year. Only allowing first-year savings to count towards the target ensures that each year only new measures will be accredited. Allowing for first year savings only or allowing only short lifetimes of savings may have the impact of promoting only measures with short payback times instead of comprehensive solutions that are likely to have longer payback times.

\footnotetext{
${ }^{11}$ Note that in the case of electricity savings there is an overlap between the ETS and white certificate schemes: reduced electricity consumption due to the implementation of energy saving obligations free allowances for power producers.
} 
Energy saving obligations and white certificates in transport

\section{$2.2 \quad$ Obliged parties}

A second step is to define the obliged actors and how to allocate the overall target to the individual obliged parties. It is important to have a significantly large share of energy consumption covered by the obligation, while retaining a manageable number of obliged parties by possibly excluding very small market actors for whom the savings obligation may pose a big burden and whose inclusion may increase disproportionately the administration costs of the system. The target allocation among obliged parties can be based on historic market shares or the number of consumers (linear or increasing for larger obliged parties).

The UK and France have chosen to impose the obligation on energy suppliers (retail companies). Italy, Denmark and Flanders have placed energy distributors (distribution network operators) under the obligation. Suppliers

10 have strong links to the final consumer, may have the motivation to offer value-added services and are uniquely placed to provide information about consumption through billing and metering processes and to inform consumers about measures on offer. Obligations may encourage them to transform their business model away from pure commodity sales and towards energy service sale.

Target apportionment among obliged parties can be based on market share or number of consumers. The size of 15 the target can increase linearly or not linearly with the obliged party size. In all existing schemes in the EU target apportionment is linear. In the UK the target apportionment into individual companies' targets is based on the number of domestic customers served. In Italy it is based on the market share of each company, while in the first obligation period in France it was based on turnover (75\%) and market shares of energy sales (25\%) in the residential and tertiary sectors. In the UK suppliers with more than 50,000 domestic customers in 2007 are under

20 CERT. In Italy annual targets are imposed on distributors with more than 50,000 customers two years before (e.g. in 2007 for the 2009 targets) ${ }^{12}$. In the first phase of the energy saving obligations in France suppliers above $0.4 \mathrm{GWh} / \mathrm{y}$ were under obligations $(0.1 \mathrm{GWh} / \mathrm{y}$ in the case of LPG and no threshold in the case of heating oil).

In Denmark the targets are set in the framework of a voluntary agreement. In the case of district heating, there is no voluntary agreement; instead every single district heating system has an executive order and has an individual target set.

In Flanders individual targets are defined annually based on $2 \%$ of the amount of electricity supplied to household customers two years previously and $1.5 \%$ for the non-residential sector, i.e. the $\mathrm{kWh}$ distributed in the

\footnotetext{
${ }^{12}$ Prior to the legislative changes in 2008, the threshold was set at 100,000 customers. As a result of this fairly high threshold, approximately one fifth of the total obligation in Italy was not been distributed, which corresponded to the volume of small suppliers.
} 


\section{Energy saving obligations and white certificates in transport}

residential and non-residential sector carry different weight in defining the annual target. This approach is very common in the Energy Efficiency Resource Standards (EERSs) in the US.

\section{$2.3 \quad$ Eligible sectors and projects}

At a third step, the regulator defines the types of projects and technologies eligible to generate savings towards

5 the targets under the scheme. It needs to be re-emphasized here that there is a difference between the scope of the obligation (which economic actors need to meet targets) and the scope of eligible sectors (where economic actors can implement projects that contribute towards the target). In Italy and France projects that deliver energy savings in transport can be certified, but as of 2009 there are no saving obligations on transport fuel suppliers.

10 The scheme can be completely open to account for savings from any technology, form of energy or end-use sector, or it might be limited with respect to technologies (e.g. establishing a list of eligible project types), enduse sectors (e.g. limit projects to certain sectors) or energies (e.g. limit to grid-bound projects). However, the economic textbook argument is to not limit eligibility because this could lead to higher costs of compliance than if the market forces were left to determine the least-cost path to the environmental or social objective.

15 There are some practical arguments against a comprehensive scheme that is completely open in terms of technologies and sectors. A purely operational consideration against extensive scope is that inclusion of all project types and all sectors may result in difficult and expensive validation of the additionality of the projects and monitoring of savings and a tremendous amount of work for regulators to design monitoring and verification methodologies. Because cost minimization is an inherent feature of markets, a completely open scheme is likely 20 to focus compliance on large-scale projects, where savings are easy to monitor and economies of scale and straightforward monitoring are likely to bring a reduction in transaction costs of certification. Such a trend however may leave out certain hard-to-reach sectors, such as residential buildings.

To meet their obligation companies in Italy are allowed to implement projects in all end-use sectors, while in the UK projects can only be implemented in the residential sector. In the UK $40 \%$ of the target must be achieved by 25 measures in the priority group, defined as vulnerable and low-income households, including those in receipt of certain income/disability benefits and pensioners over $70^{13}$. In Denmark all end-use sectors apart from transport are allowed; no supply side and network-related measures are allowed at present and fuel switch is only allowed

\footnotetext{
${ }^{13}$ A new scheme - called Community Energy Saving Programme (CESP) - runs in the UK from September 2009 until the end of 2012 targeting homes in areas of low income. This is a new obligation (though based on CERT) on suppliers and generators. The six largest suppliers account for $96 \%$ of the obligation expected to target around 90,000 households in about 100 projects across Great Britain.
} 


\section{Energy saving obligations and white certificates in transport}

if it reduces final consumption. Transport-related projects are not allowed, unless they concern internal transport consumption of a company. In Flanders residential, non-energy intensive industry and service sectors are allowed. The French system only excludes projects in sectors under the ETS. Illustrative or open lists of eligible measures are usually defined in advance by the authority administering the scheme based on the relevant legal

5 provisions. Using lists of measures allows the regulator to implicitly promote certain types of measures (e.g. via longer lifetimes) and to calculate the average cost of these measures. Most countries have open or illustrative lists of measures, mostly related to establishing standard saving values (default values for unitary savings, see later). Other measures need the pre-approval of the regulator on case-by-case basis. In Flanders measures must always consist of financial contribution and an awareness-raising element.

10 The national systems differ in terms of allowing parties that are not under the savings obligations to get their project savings certified. The UK and the Flemish schemes are closed with savings accredited only to the obliged parties. In Italy and France, subject to various conditions ${ }^{14}$, other economic actors or public bodies can receive certificates too. In Denmark distributors are not allowed to directly implement projects other than information and informative bills; they comply with the targets acting via their daughter companies that carry

15 out activities related to meeting the obligations or via contracts with third parties ${ }^{15}$.

In the UK the supplier obligation has been introduced with the intention of, among other things, changing business models in energy supply. It has been observed that the major household energy suppliers have developed their own programs, used to some extent as a marketing tool. Nevertheless, energy efficiency programs have remained a separate operation from the core activity of selling energy units. Different is the 20 situation in Italy, where the scheme has boasted the development of a market for energy efficiency services. In Italy the largest share of TWC - more than three quarters - has been issued to energy service providers. In France, the majority of obliged parties have developed new services in the household energy market, such as advice, individual audits, financial instruments like low-interest rate loans and upfront subsidies. These build on partnerships with retailers, installers, manufacturers and banks. These partnerships have helped to structure and organize installation sector offers in the household sector.

\section{4 \\ Results to date and lessons learnt}

\footnotetext{
${ }^{14}$ For example in France economic actors that are not under the obligation cannot certify savings from projects that lead to an increase their turnover. It needs to be pointed out that many energy service providers in France indeed supply energy too and hence are under the obligation.

${ }^{15}$ The Danish Energy Association tried public tendering to achieve a minor share of its target (around 5\%) on two occasions. Industrial companies were invited to bid in projects, but too few bids were received and the amount was not spent. So far direct contracting has worked better (Schalburg 2009).
} 


\section{Energy saving obligations and white certificates in transport}

Table 1 summarizes the key design features of the ongoing phases of the schemes in Italy, France, Denmark, Flanders and the UK. A few general policy observations (sub-section 2.4.1), along with a few technical/operational remarks (sub-section 2.4.2), follow ${ }^{16}$.

\section{Table 1. Major design features of current supplier obligation systems in the EU}

\begin{tabular}{|c|c|c|c|c|c|}
\hline & UK (CERT) & Italy & France & Denmark & $\begin{array}{c}\text { Flemish region } \\
(\mathrm{BE})\end{array}$ \\
\hline Current target & $\begin{array}{l}\text { Carbon: } \\
185 \mathrm{MtCO}_{2} \\
\text { lifetime in } 2012\end{array}$ & $\begin{array}{l}\text { Primary energy: } \\
\text { at least } 22.4 \text { Mtoe ( } 260 \\
\text { TWh) to be saved } \\
\text { between } 2005 \text { and } 2012 \\
\text { of which } 6 \text { Mtoe }(\sim 70 \\
\text { TWh) to be saved in } \\
2012 \text { only. }\end{array}$ & $\begin{array}{l}\text { Final energy: } 54 \mathrm{TWh} \\
\text { lifetime discounted }\end{array}$ & $\begin{array}{l}\text { Final energy: } 2.95 \\
\text { PJ ( 0.82 TWh) } \\
\text { annual (as of } 2010 \text { : } \\
5.4 \mathrm{PJ} / \mathrm{y}=1.5 \\
\text { TWh/y) }\end{array}$ & $\begin{array}{l}\text { Primary energy: } \\
0.58 \text { TWh for } \\
2008 \text { (annual) }\end{array}$ \\
\hline Current phase & $2008-2012$ & $\begin{array}{l}\text { 2005-2012 } \\
\text { (annual targets) }\end{array}$ & $\begin{array}{l}\text { Mid-2006 to mid- } \\
2009\end{array}$ & $\begin{array}{l}\text { 2006-2013 (annual } \\
\text { targets) }\end{array}$ & $\begin{array}{l}2003- \\
\text { (annual targets) }\end{array}$ \\
\hline $\begin{array}{l}\text { Annual end- } \\
\text { use energy } \\
\text { savings (TWh) }\end{array}$ & $3.5^{b}$ & $4.5^{\mathrm{c}}$ & $1.3^{\mathrm{d}}$ & & \\
\hline $\begin{array}{l}\text { Sectoral } \\
\text { coverage for } \\
\text { eligible } \\
\text { projects }\end{array}$ & $\begin{array}{l}\text { Residential } \\
\text { consumers only }\end{array}$ & All consumers & All except ETS & All except transport & $\begin{array}{l}\text { Residential and } \\
\text { non energy } \\
\text { intensive } \\
\text { industry and } \\
\text { service } \\
\end{array}$ \\
\hline $\begin{array}{l}\text { Restrictions on } \\
\text { compliance }\end{array}$ & $\begin{array}{l}40 \% \text { from } \\
\text { 'priority group' } \\
(50 \% \text { in EEC) }\end{array}$ & $\begin{array}{l}50 \% \text { from reduction in } \\
\text { own energy sector } \\
\text { (applied until January } \\
\text { 2008) }\end{array}$ & & & \\
\hline Obliged parties & $\begin{array}{l}\text { Electricity and } \\
\text { gas suppliers } \\
\text { above } 50,000 \\
\text { residential } \\
\text { customers }\end{array}$ & $\begin{array}{l}\text { Electricity and gas } \\
\text { distributors above } \\
50,000 \text { customers }\end{array}$ & $\begin{array}{l}\text { Suppliers of } \\
\text { electricity, natural } \\
\text { gas, heat, cold and } \\
\text { above } 0.4 \mathrm{TWh} / \mathrm{year} \\
\text { sales, LPG above } 0.1 \\
\text { TWh yearly sales and } \\
\text { all heating fuel } \\
\text { suppliers. }\end{array}$ & $\begin{array}{l}\text { Electricity, gas and } \\
\text { heat distributors }\end{array}$ & $\begin{array}{l}\text { Electricity } \\
\text { distributors } \\
\text { Separate targets } \\
\text { for residential } \\
\text { and non- } \\
\text { residential } \\
\text { (2008 on) }\end{array}$ \\
\hline $\begin{array}{l}\text { Eligible parties } \\
\text { for savings } \\
\text { accreditation }\end{array}$ & $\begin{array}{l}\text { Gas and } \\
\text { electricity } \\
\text { suppliers only } \\
\text { can achieve } \\
\text { accredited } \\
\text { savings }\end{array}$ & $\begin{array}{l}\text { ESCOs, energy } \\
\text { efficiency installers, } \\
\text { private and public } \\
\text { enterprises with an } \\
\text { energy manager, non } \\
\text { obliged gas and } \\
\text { electricity distributors }\end{array}$ & $\begin{array}{l}\text { Any economic actor } \\
\text { but restriction on non } \\
\text { obligated parties }\end{array}$ & $\begin{array}{l}\text { Obliged distributors } \\
\text { and daughter } \\
\text { companies }\end{array}$ & $\begin{array}{l}\text { Electricity } \\
\text { distributors only }\end{array}$ \\
\hline $\begin{array}{l}\text { Certification } \\
\text { size; discount } \\
\text { factor; explicit } \\
\text { cost recovery }\end{array}$ & $\begin{array}{l}\text { N/A } \\
\text { certification; } \\
\text { No discount } \\
\text { factor in CERT; } \\
\text { No explicit cost } \\
\text { recovery. }\end{array}$ & $\begin{array}{l}1 \text { toe; } \\
\text { No discount factor; } \\
100 \text { Euro/toe cost } \\
\text { recovery until } 2008 \text {. As } \\
\text { of } 2009 \text { cost recovery } \\
\text { depends on energy sale } \\
\text { price variation. }\end{array}$ & $\begin{array}{l}\text { Min. } 1 \mathrm{GWh} \\
\text { certification } \\
\text { application threshold; } \\
4 \% \text { discount factor } \\
\text { except for } 1^{\text {st }} \text { year.; } \\
\text { No effective cost } \\
\text { recovery }{ }^{\mathrm{e}} \text {. }\end{array}$ & $\begin{array}{l}\text { N/A } \\
\text { First-year savings } \\
\text { only count } \\
\text { Cost recovery }\end{array}$ & $\begin{array}{l}\text { N/A } \\
\text { First-year } \\
\text { savings only } \\
\text { Cost recovery } \\
\text { determined } \\
\text { based on annual } \\
\text { action plans for } \\
\text { compliance }\end{array}$ \\
\hline Trading & $\begin{array}{l}\text { Energy savings } \\
\text { can be traded } \\
\text { only between } \\
\text { obligated } \\
\text { parties; }\end{array}$ & $\begin{array}{l}\text { Certificate trade; } \\
\text { Spot market sessions; } \\
\text { OTC trading; }\end{array}$ & $\begin{array}{l}\text { Certificate trade, only } \\
\text { OTC trading }\end{array}$ & $\begin{array}{l}\text { No trading, no } \\
\text { certificates }\end{array}$ & No trading \\
\hline
\end{tabular}

\footnotetext{
${ }^{16}$ For more information on the current status of the schemes, see Oikonomou 2010.
} 
Energy saving obligations and white certificates in transport

1

2

3

4

5

6

7

8

9

10

11

12

13

14

\subsubsection{Policy conclusions}

As experience in the EU shows, there are various ways to frame energy saving obligations in terms of level of

10 ambition, size and unit of obligation, obliged parties, eligible energies, sectors and measures. The design of energy saving obligations and TWCs inevitably influences their performance and output (see Bertoldi et al. 2010). Below, we point to a number of issues that can be transferred to implementing the concept in the transport sector.

Primarily, targets under all such schemes have been met or exceeded, often at a cost below the anticipated one.

15 In the UK and France obliged parties are moving in the direction of positioning themselves as providers of energy efficiency vis-à-vis their clients, forming partnerships with energy efficiency industries, bringing new activities without significantly modifying their core business of selling energy units. In Italy obligations have been mostly delivered by energy service providers. In the medium term this cooperation may expand the scope of commonly implemented projects to the tertiary and industrial sectors, where ESCOs have more experience,

20 and once 'low-hanging fruits' are exhausted.

Secondly, most schemes focus on end-use sectors and are dominated by subsidy measures mostly targeting the residential sector, where financial incentives play an important role. For the large majority of measures implemented, standardized saving values have been used reducing transaction and administration costs. The administrative costs of implementing energy saving obligations and tradable white certificates are a function of 25 the scope and simplicity of the system.

Thirdly, whether certification of energy savings and certificate trading add value to supplier obligation depends on at least two major factors. Certificate trading can potentially contribute to increase in the cost-effectiveness of a supplier obligation scheme and make it a preferable option with respect to other policy instruments for energy 


\section{Energy saving obligations and white certificates in transport}

saving (e.g. energy taxes) only when the energy saving target established is sufficiently high with respect to the existing saving potential in the sector(s) covered by the scheme. In general the more ambitious the saving target gets, and the more variation there is in energy saving unit-costs and end-use energy prices, the greater scope there is for a TWC scheme to outperform other energy policy instruments (Oikonomou et al. 2010).

5 The role of trading in a scheme that is limited in scope (e.g. residential sector only) is more ambiguous: the additional administration cost of establishing and operating a trading regime may not justify the cost efficiency gains of trading for obliged parties and society. Since most suppliers work with a number of contractors and retailers, the implementation costs that different obliged parties pay are similar. However, there is considerable variation between energy suppliers in the mix of energy saving measures they employ to meet their targets.

10 Finally, in existing schemes the policy additionality of supplier obligation and TWC schemes has not been clear. For example, in France existing substantial tax credits for certain energy efficiency improvements seem to be more important in financing most of the interventions. Obliged parties under energy saving obligations rely on local contractors and offer very small incentives (rebates) ${ }^{17}$. In the UK and Italy obliged parties tend to partly subsidize the energy efficiency intervention, especially in the case of low-cost measures (e.g. compact 15 fluorescent lamps). However, starting from mid-2008 tax credits play an important role in Italy too and it is not clear which policy is the driver for a project to be implemented: the rebate given by obliged parties as part of their progress on targets or tax credits available for certain energy efficiency measures. In the UK in the case of insulation in social housing, obliged parties sign contract with social housing providers.

These observations point to the idea that energy saving obligations and TWCs may have a role in the transport sector in order to bring together a combination of a mandate to deliver a certain amount of savings from costeffective projects, a financing channel to (partially) cover the associated investment needs (cost recovery or pass through of costs to the end-user) and possibly the flexibility of compliance associated with certificate trading. There are at least two major areas where the transfer of experience with existing energy saving obligations and TWC schemes to the implementation in the transport sector is expected to be of limited use. First, measurement and verification of energy savings from transport projects - including establishing baselines and adopting methodologies for both technical and behavioral measures - is expected to pose difficulties due to the limited track record in measuring energy savings from transport in existing energy saving obligations and beyond. Second, the implementation of the concept may need to be managed by another type of authority, not by the

\footnotetext{
${ }^{17}$ Nevertheless, one needs to keep in mind that in France residential tariffs are regulated and there is no cost recovery: hence obliged parties are not passing on the costs in any standard way.
} 
Energy saving obligations and white certificates in transport

energy regulator, as is mostly the case with existing schemes: unlike grid bound energies, transport fuels (with the exception of oil markets) are not regulated markets.

\subsubsection{Technical/operational remarks}

Based on the review and analysis of European schemes provided in the previous sections, the following lessons can be drawn about the design and operation of supplier and utility obligations and tradable certificate schemes (Bertoldi et al. 2010):

- Supplier obligations encourage energy market actors into energy efficiency without necessarily changing their business models from selling energy into selling energy services, at least in the short term;

10 - Many design modalities - such as size of the saving potential in the sectors under obligation, the size and nature of the obligation, the decision between annual or lifetime saving targets, obliged parties, sectoral and energy coverage, and the status of market liberalization - reflect national policy priorities;

- Supplier obligations and TWC schemes are well-suited to deliver low-cost and standard energy efficiency measures. Nevertheless, they can be designed to channel efforts towards measures with 15 higher upfront investment needs (e.g. by using estimates of technical lifetimes of the measures or by giving longer validity to certificates);

- Providing administrative and monitoring costs are not disproportionate in opening up the generation of TWCs to any party (not just the obligated energy companies), then this approach should theoretically ensure diverging marginal costs and lower risks of market power and speculative behavior. Allowing third parties to certify project savings is an opportunity to develop an energy services activity rather than to constrain the obliged parties to evolve toward such activities;

- Obliged parties expect to recover the costs of compliance with the obligation in some way (cost recovery as in Italy or passing through in end-user prices as in the UK);

- Defining standard measurement and verification methodologies reduce the transaction costs for obliged parties and project developers and thus directs the market towards types of projects or sectors, where such standard methodologies ('deemed savings') are available. Thus, the co-existence of default values for unitary energy savings and of more detailed measurement and verification methodologies results in a bias towards measures that introduce energy efficiency technologies with default values for unitary energy savings; 


\section{Energy saving obligations and white certificates in transport}

- Minimum buy-out prices and penalties may act to establish a ceiling and a floor price. Banking of certificates or savings, long validity of certificates and long compliance periods mitigate price risks for obliged and eligible parties, but may discourage trading and thus reduce liquidity in the current compliance period;

- Administrative costs of all policy instruments are a function of the simplicity of the system and the ease of obtaining reliable information necessary for its design and enforcement. The relatively low burden for the UK authority results from a single eligible sector (residential), rather limited number of obliged parties, ex-ante measurement and verification approach, as well as lack of third party trading provisions;

10 - Trading is expected to deliver cost efficiency gains when energy saving targets are set sufficiently high with respect to the existing economic saving potential in the sectors covered by obligations. The more challenging the obligation is, the greater the benefit of trading as it brings diversity in the marginal costs of compliance among trading parties. The higher the target, the more likely it is that the obliged actors can reduce compliance costs by trading and that certificate trading can actually deliver cost efficiency 15 gains. Other design modalities also affect the role of trading. Trading appears essential in a system with a wide scope in terms of sectoral coverage, project types and non-obliged parties are allowed to trade in. This is the case in Italy where trading is an important element. In contrast, despite the rather wide scope of the French scheme, suppliers have chosen to do projects themselves or via partnerships in order to position themselves as providers of energy services. In addition in France residential electricity 20 and gas tariffs are regulated: there is no explicit cost recovery and obliged parties are reluctant to let other economic actors make profit from 'their' clients. Finally, in France economic actors can certify project savings only if projects do not increase their turnover.

- The choice of primary or final energy influence the balance between savings on gas and electricity: for example in Italy, where obligations are in primary energy and lifetimes are set at 5 years $(8$ years in 25 exceptional cases), most savings have occurred in electricity. Long lifetimes for certain measures and the availability of standardized savings values for certain types of projects influence the compliance choices towards such projects or sectors.

- As in any market, an efficiently working tradable certificate market requires transparency i.e. that all players know the price of certificates in the market, the possibilities for the purchase and sale of 
certificates and possess information on the types and costs of energy saving technologies and processes in the market.

\section{Savings obligations and tradable certificates: possible applications in} transport

5 In mid 2009 the first voluntary application of a scheme aiming to deliver energy savings in transport was introduced in the UK. The details are outlined below. However, it needs to be emphasized that this application is more of a self-declaration or self-commitment to deploy a range of soft informative measures without a very clear mechanisms to deliver project-based energy savings. In contrast, the concept proposed in this paper is based on the concept of a mandatory energy saving target, possibility to recover compliance-related costs and 10 trade project-based savings, and a non-compliance penalty charged.

In the UK the Department for Transport has developed a voluntary Energy Efficiency Agreement with road transport fuel suppliers to meet the requirements of the Energy Services Directive. The Agreement applies to anyone who sells road transport fuel to the end-user. This includes anyone who runs a petrol station, sells fuel from a pump, or who sells fuel through other sites such as bunkering sites or sells direct to businesses.

15 Companies that sign the agreement include major oil companies who own/run petrol stations, companies that run franchised petrol stations, companies that run independent petrol stations, shops or garages with fuel pumps that are not purely for their own use, companies who sell fuel to companies such as bus operators, haulage companies, car fleets, etc., fuel card companies who own the fuel they manage.

In signing the agreement, companies agree to make sure that their customers have access to at least one fuel efficiency measure and to advertise/promote the measure(s) to their customers. Companies agree to make sure their customers have access to the measures, and promote them, for at least 4 weeks every year.

In the Energy Efficiency Agreement fuel efficiency improvement measures are defined as any action that normally results in the more efficient use of fuel. The Agreement includes a list of fuel efficiency improvement measures to choose from, such as provision and promotion of tyre pressure gauges and air pumps (either for sale 25 or available for use on forecourts), of high performance engine oils with proven fuel efficiency benefits over standard oils, of advanced fuels with proven fuel efficiency benefits over standard fuels, of eco-driving lessons, vehicle maintenance checks, low rolling resistance tyres, fuel efficiency audits which include tailored advice on 


\section{Energy saving obligations and white certificates in transport}

consumer actions. Any further measures that meet the definitions of the Energy Services Directive can be introduced after a check with the Department for Transport.

Companies can offer the measures themselves, for example by selling tyre pressure gauges or advanced fuels, or indirectly through a contract or agreement with a third party, for example an agreement with a driving school to

5 provide eco-driving lessons to their customers. Companies do not have to pay for this type of service (i.e. the lessons), they just need to make sure it is available to their customers. Companies can promote the fuel efficiency measures via simple ways such as posters, leaflets or nozzle collars, also making use of a range of government produced marketing material available free of charge. Larger-scale marketing campaigns might include, for example: promoting lessons and events through discounted rates; offering a free lesson, vehicle

10 check or entry to an event to certain customers; as part of a customer loyalty scheme. Advertising could be through point of sale material (e.g. hand-outs, crowners, etc.), websites, newsletters or other similar routes.

This newly introduced scheme offers a first attempt to introduce the basic concept of transport fuel suppliers delivering energy saving measures. In the view of the authors, an important element is missing however: the Energy Efficiency Agreements are voluntary ones and there is no energy saving obligation. We argue that a voluntary approach, combined with a focus on information and promotion measures, risks delivering a limited amount of savings. Clear guidance on reporting and, in particular, on measurement and verification of savings is a pre-requisite for a scheme delivering real results. These seem to be missing. Nevertheless, the Energy Efficiency Agreements may be seen as a first voluntary pilot test of the concept.

The promotion of technical and behavioral measures delivering energy savings and energy efficiency 20 improvements can be accelerated by the introduction of energy saving obligations and TWCs in the transport sector. In this section we look at the basics of a possible scheme with saving obligations and tradable certificates in the transport sector, namely obliged parties and eligible projects. Because this paper aims to open the discussion on the topic, at this point we leave out important yet secondary technical aspects, such as trading modalities or monitoring and verification.

25 The introduction of energy saving obligations and tradable certificates in the transport sector might pursue operative aims (e.g. traffic avoidance, mode shift and traffic guidance) or strategic aims (e.g. mobility needs, transport security, economic profitability, vulnerability of energy supply, environmental aspects, and generating revenues). An energy saving quota could be imposed on some category of transport operators (fuel suppliers, car manufactures, transport and freight operators or drivers) and could be coupled with a trading system for transport measures resulting in energy savings verified by the regulator and certified by means of TWCs. 
Energy saving obligations and white certificates in transport

Evaluating the applicability of energy saving obligations and TWCs to the transport sector involves breaking down the potential 'system boundaries' into a number of elements as follows:

- On which transport actor does the obligation fall?

- In what unit would the obligation (reduction target) be expressed?

- What types of projects would be allowed?

- Will it be ring fenced around transport fuels or linked with electricity and gas supplier obligations?

These issues are analyzed in the sections below.

\section{W.1 Who are the obligated parties in the transport sector?}

When defining the obligated parties in transport the link within the energy flow chain should be taken into

10 account. Thus influencing one link of the energy flow chain has a similar impact on all subsequent links but might substantially change the transaction costs of the scheme. Hence the question whether an energy saving target is introduced up-, mid-, or downstream is crucial. In this section we look at different options for obliged parties and sectoral coverage and propose that energy saving obligations and TWCs are focused on surface passenger transport and placing transport fuel suppliers and large distributors under the obligation.

15 It has already been discussed that road transport has a large share in transport energy consumption (about 90\%) and $\mathrm{CO}_{2}$ emissions. For this reason the authors propose to initially consider a limited scheme that covers operators and measures in road transport only. Furthermore, one might consider starting with the introduction of energy saving obligations and TWCs within the limits of regional areas or for sub-sectors such as road freight transport.

20 The authors propose to leave aviation and maritime transport outside energy saving obligations. Aviation emissions from all flights starting and landing in the EU will be included in the EU ETS from 2012. There are discussions underway about the inclusion of emissions from shipping and surface transport under this scheme (EC 2007).

Even if an energy savings target is limited to road transport, a wide variety of tradable obligations on different 25 actors are possible. An energy savings quota with or without a trading system could be imposed on fuel importers or fuel producers, such as refineries (upstream approach), car manufactures or transport fuel distributors and suppliers (midstream approach), transport and freight operators or individual drivers themselves (downstream approach). The implications of these choices are discussed below. 


\section{Energy saving obligations and white certificates in transport}

\section{Fuel producers (upstream)}

An upstream system targeting fuel producers (i.e. oil refineries or fuel importers) would cover a manageable number of about 1000 participants in the EU - likely to be high enough to ensure an efficient trading and low enough to be manageable to administer and monitor. The relevant data needed to design the obligation is already available as it is used for the national energy inventories or value-added tax. In the US the phase-out of lead in gasoline is an example of successful implementation of upstream tradable permits to fuel quality standards ${ }^{18}$. In the EU, however, oil refineries are already under the EU ETS for their directly generated $\mathrm{CO}_{2}$ emissions. Because of this fact and due to their limited contact with final consumers, fuel producers are likely to have limited opportunity to implement energy efficiency projects and hence are considered inappropriate target for

10 energy saving targets.

\section{Fuel distributors and suppliers (midstream)}

Transport fuel distributors and suppliers, which distribute and retail fuels to final customers are positioned close to and have regular contact with the end user. While the own energy saving potential of fuel distributors and suppliers is doubtful, they are well-positioned to work with third parties (contractors) the way Italian electricity and gas distributors cooperate with energy service companies (ESCOs). This can open new market niches for fuel distributors and suppliers, just as some fuel suppliers have established chains of fast food restaurants, car wash or car maintenance services.

Fuel suppliers might try to initiate energy efficiency programs and recover the extra cost for doing so via a small charge in the price of fuel sold, which offers a project-financing channel. Alternatively such a levy could be introduced by law, and earmarked for cost-recovery. Obligations may be set in a straightforward manner as percentage of their annual sales.

For all these reasons the authors of the paper believe that energy saving obligations should target fuel distributors and suppliers.

\section{Car manufacturers (midstream)}

25 A mid-stream system focused on car manufacturers is not deemed to be desirable because of already existing tools and commitments (the $120 \mathrm{~g} \mathrm{CO}_{2} / \mathrm{km}$ target, car labelling, etc.) and because it is not expected that energy saving obligations and TWCs in this part of the chain will foster advances in vehicle technology. On the other hand, component suppliers can be allowed to certify energy savings resulting from their projects (e.g. tyres,

\footnotetext{
${ }^{18}$ The lead rights trading program between refineries between 1982 and 1988 accelerated the phase-out of lead in gasoline until a complete ban came into effect in 1996 (Raux 2004).
} 
Energy saving obligations and white certificates in transport

lubricants, air condition etc.) and can receive compensation for doing so from economic actors under the transport obligation. This leads to an additional incentive for component suppliers to optimize the energy efficiency of their products.

\section{Traffic participants (downstream)}

5 In principle it would be possible to put obligations to save transport fuel on individual travelers and freight operators, rather than suppliers. The obvious advantage is that it would directly incentivize users to invest in more efficiency vehicles and change their travel behavior, rather than acting via suppliers (Harwatt 2008; Raux and Marlot 2004).

A downstream solution may be to put obligations on specific groups of transport fuel users who have good 10 energy efficiency opportunities, such as freight transport operators. Introducing obligations for freight operators has the advantages of economies of scale in terms of large savings per actor than passenger transport and of using existing reporting and bookkeeping of companies for monitoring and verification. Further, a downstream solution could be a combination of tolls (price instrument) and rationing rates (quantity instrument) or quotas for vehicle kilometers travelled within a given urban area for motorists that could be transferred among them, as an

15 alternative to pure congestion pricing given the issue of acceptability (see Raux 2004 and sources herein). For example, vehicle owners can be provided with an amount of free units ('rights' to purchase fuel). If they need to go beyond the allowance provided, they must pay. At the same time those who spare some of the initially distributed rights may be allowed to return them to obtain either a monetary or fiscal transfer ('subsidy') (Frisoni 2007). Raux (2004) shows examples that it is technically possible to apply a quota-based system of permits to 20 mobile sources within a defined area with a small number of readily controllable points of entry and exit.

Yet, the administrative costs of such a downstream system - that resembles personal carbon trading - could be significant as a huge number of transport operators would need to be placed under the obligation in order to ensure adequate coverage.

\subsection{Stand-alone scheme or integrated?}

25 Even though in Italy and France transport projects are eligible for certification in existing supplier obligations and TWC schemes, in Europe a very small amount (in France only) of energy savings have come from transport measures. While in the Italian scheme initially the lack of cost recovery for primary energy has influenced the types of project implemented, the transport sector in itself is a hard-to-reach in sustainability terms and its 


\section{Energy saving obligations and white certificates in transport}

introduction under an energy saving obligation and TWC scheme on grid-bound energies may produce very limited results in terms of implementing transport projects.

For these reasons we recommend, at least in an initial phase, a "closed" national stand-alone obligation limited only to transport sector projects (excluding aviation) rather than an open system where transport obliged parties

5 could also obtain certificates in electricity and gas savings. A midstream system with obligations imposed on fuel distributors and suppliers and expressed in savings in amount of fuel can act as a pilot test for the concept. The system could co-exist with taxation: the tax will be paid by market actors that, due to their small size, are outside the obligations and by obliged parties who fail to meet their targets and fail to purchase certificates in the form of sanctions, which acts as a ceiling on certificate price (see also Raux and Marlot 2004).

$10 \quad 3.3 \quad$ In what units would the obligation be expressed?

The energy saving obligations are specified either in absolute terms (in tons of $\mathrm{CO}_{2}$ or $\mathrm{MWh}$ saved) or relative to energy sales at the start of the timeframe. Energy saving obligations started off being applied to primary energy (through the Energy Efficiency Commitment, whose predecessor - the Energy Efficiency Standards of Performance is the oldest supplier obligation in Europe) and changed to carbon (e.g. Carbon Emissions

15 Reduction Target in the UK), thus moving from a focus on merely energy efficiency to incorporating more innovation including fuel switching incentives.

The obligation on the transport sector might be focused on primary energy (litres of fuel), carbon, fuel efficiency of cars, fuel efficient driving of traffic participants, vehicle mileage travelled, passenger or tonne kilometres, air pollutants, biofuels etc. Renewable fuel projects might be allowed too. When choosing the unit of 20 obligation a few factors need to be taken into consideration. First, the nature of the policy aim pursued, i.e. is it an operative aim (e.g. traffic avoidance, mode shift and traffic guidance) or a strategic aim (e.g. mobility needs, transport security, economic profitability, vulnerability of energy supply, environmental aspects, and generating revenues)? Second, the ease of monitoring compliance. Finally, the adequacy of targets imposed at different levels in terms of expected results, energy saving potential and the acceptance of targets by different actors.

25 Allocation criteria are needed to apportion the sectoral target into individual ones. In mid- or downstream system, an allocation according the historic volumes of distributed energy within the last year(s) might be a straightforward solution. A further option would be the allocation according the number of served customers which may however be complicated in road transport. 
Energy saving obligations and white certificates in transport

A crucial step in the development of energy saving targets is the identification of the eligible energy saving measures that would be implemented to comply with obligations. As discussed in section 3.2 , the authors of this paper argue that, at least initially, energy saving obligations in the transport sector should be kept separate from general energy saving obligations on energy suppliers rather than extending energy suppliers obligations to

5 cover transport distributors and suppliers. In addition, only transport projects should count towards energy saving obligation in the transport sector.

This is recommended in order to target hard-to-reach energy efficiency and energy savings from the transport sector, where barriers are strong and price elasticities are low. In addition, market distortions may occur if putting under the obligation both market actors subject to some form of price regulations (e.g. electricity and gas

10 tariffs in the residential sectors in some countries) and market actors that are not subject to such price regulations (e.g. heating oil suppliers or transport fuel suppliers). Heating oil suppliers or transport fuel suppliers may have a competitive advantage in terms of passing through in end-use prices all costs incurred in complying with the energy saving target, while regulated entities are not allowed to do this. The second phase of the French obligation will test this issue by including transport fuel suppliers under a generic energy saving obligation 15 covering suppliers of electricity, natural gas, heating, cooling, heating oil, LPG.

There are a number of ways in which energy demand or carbon emissions from the transport sector can be reduced. These effectively fall into five categories:

1. Improving vehicle technology. The technical improvements for passenger cars are mainly given by alternative technologies (electrification, batteries, fuel cells etc.), advanced fuels, downsizing of engines 20 and vehicles, reduction of friction within the engine, new lubricants, fuel economy meters, intelligent speed adaptors, tyre pressure indicators, low rolling resistance tyres (now getting labeled in the EU), improvement of the circulation of hot and cold air within the vehicle and the circulation of the power assisted steering, automotive lightweight construction, further improvement of combustion within the engine, aerodynamics and optimized gear choice systems, etc.

25 2. Developing lower carbon fuels. The improvement of the energy mix for electric cars and the development of "second generation" biofuels (by Fischer-Tropsch gas-to-liquids technology) are promising alternatives to fossil fuels. Currently, the carbon emission reduction potential is however still limited (Larivé et al., 2004; Bringezu et. al. 2009).

3. Increasing the efficiency with which vehicles are used (occupancy rates and driving style). In 


\section{Energy saving obligations and white certificates in transport}

improved through eco-driving campaigns. In freight transport possible projects include improved logistics and driver training.

4. Ensuring that the most efficient vehicles are used on any given journey. Support for mode shift to more efficient modes (for both passenger and freight) can materialise from a number of initiatives from 'hard' infrastructure provision to 'soft' information campaigns, ticketing and marketing initiatives and travel planning at workplaces, schools and other trip generators. In the UK, 'smarter choices' is the term given to packages of so-called 'soft measures' which aim to change transport behavior. This includes the promotion of car-share clubs and personalised and work-based travel plans to encourage uptake of alternatives to the car and the use of telecommunication for work purposes. Such policies have been shown to be highly cost effective at reducing emissions (Anable, 2005).

5. Reducing the need to travel. There are fewer explicit policy mechanisms to reduce total travel demand. However, Information Communication Technology (ICT) systems can make journeys both more efficient (shorter - e.g. through GPS based systems) and through tele-initiatives such as teleworking, video conferencing and home shopping to spatial planning for new housing and business developments. There is however a long discussion about the rebound effect of these techniques: e.g. through video conferences it is possible to communicate with many people all over the world, which might lead to further working meetings (see among others Choo et al., 2005).

The project types listed above deserve some further consideration also in the light of possible implementing parties (obliged and eligible actors). First and foremost, it needs to be emphasized that energy saving obligations are intended to foster market transformation and uptake of commercially viable technologies via cost effective projects rather than to deliver technological advancements, which are better targeted by regulation and policies to support research and development. In addition, vehicle technology has been subject to numerous incentives in various member states of the EU, among other as part of support measures to deal with the financial crisis.

Second, it is deemed appropriate to place fuel suppliers or distributors under obligation due to their proximity to the end user and the ability to recover the cost of obligation via a small charge on each liter of fuel sold (see next paragraph), but allow both them and also other economic actors without obligations - referred to as 'eligible actors' under energy saving obligation and TWC schemes - to certify savings from projects they implement. In terms of delivery channels obliged companies can offer soft measures, such as information about smart driving, car loading and tyre pressure. They can also provide public transport incentives (e.g. free bus tickets) or offer a price discount on more efficient fuels. Eligible actors may include road haulage companies, taxi companies, 


\section{Energy saving obligations and white certificates in transport}

public transport companies, transport energy service companies, but also car manufacturers, tyre manufacturers and car repair chains. Each of these eligible actors - and many more - can offer various delivery channels.

The authors recommend financing the cost of the project implementation up to the level of the obligation for each subject via a cost-recovery mechanism financed by a small fixed charge on each liter of fuel sold intended

5 to cover project costs (cost recovery). An alternative may be to allow each supplier to increase fuel price to pass through its costs of compliance (pass through). Loss of fuel sales should not be subject to any cost recovery mechanism.

It has been observed that the effectiveness of energy saving obligations and TWCs applied in the electricity and gas sectors increases if they are bundled with other policy instruments such as information campaigns and other means to promote opportunities of energy saving to drive the consumers demand for energy efficient measures even though this contradicts the pure economic theory. The introduction of the TWC scheme into a market leads to an increased demand for energy efficient goods by lowering their relative price. However, the impact on consumption may be limited. This is due to the rebound effect on the consumer behavior ${ }^{19}$. Measures which target behavioral choices could help to lock in savings and limit such losses. A further concern is that short-term 15 elasticity of transport fuel use, as complemented with durable equipment (vehicles), is much smaller than longterm elasticity (Goodwin et al. 2004).

Thus behavioral measures are even more important in transport than in other end-use sectors. Behavior changes that may be certified in a TWC system include reduced mileage, increase in the use of public transport instead of private cars, car sharing, driving slower, etc. Energy saving obligations are however untested for behavioral measures. On the one hand difficulties with establishing the savings from such projects may point to the limits of baseline-and-credit schemes. On the other hand, the involvement of 'new' actors in energy efficiency often results in bundling technical and behavioral measures. Even though the total effect of behavioral measures may be difficult to measure precisely, qualitative benefits from these measures are important and may be the primary effect of energy saving obligations. Developments with establishing methods for measurement and verification of energy savings from transport projects should be closely monitored. In France there are already four approved methodologies for transport measures ${ }^{20}$.

\footnotetext{
${ }^{19}$ Energy efficiency measures in transport lead to the reduction in cost per unit of distance travelled. This can lead in turn result in more travel, the purchase of larger cars and a corresponding increase in fuel consumption and emissions (UKERC 2007 and Frondel et al. 2007). The UK Energy Research Centre estimates that in the case of transport, the direct effect of the rebound is likely to cause a loss of emissions savings of around $10 \%$ (UKERC 2007). In the longer term, the indirect economy-wide effect, which includes embodied energy from new technologies, is likely to be higher.

${ }^{20}$ The deemed savings target bus driver training, energy efficient tires, vehicles running on cleaner fuels and recuperation on braking.
} 


\section{Energy saving obligations and white certificates in transport}

Finally, non-compliance to meet energy saving obligations either via own action, working with third parties or purchasing certified energy savings, should result in a penalty. The size of the penalty can be pre-defined (as in France) in order to establish a ceiling in the costs of compliance or linked to the average cost of compliance of all market actors (e.g. based on average certificate price). To increase the opportunity cost of non-compliance,

5 the penalty funds can be recycled as award to complying parties.

\section{Discussion}

The present paper is intended to open a wider discussion and analysis of energy saving obligations and TWCs in the transport sector. This discussion will be timely in the light of the expected inclusion of transport fuel suppliers under the French energy saving obligation and given that a first attempt to engage transport fuel 10 suppliers in energy efficiency has been introduced on voluntary terms in the UK.

The authors of this paper deem transport fuel distributors and suppliers to be the most appropriate parties on which to impose energy saving obligations. The obligation could be imposed on fuel suppliers above a certain threshold of annual sales. Concerning the scope of eligible projects, limiting projects to those in the transport sector, at least initially, will foster much needed energy and emission savings in this sector. This is the case even

15 if this may result in higher economic costs of implementing a stand-alone transport scheme than an integrated scheme of energy saving obligations and TWCs where the obligated parties can implement projects and buy certificates from other end-use sectors. The authors recommend financing the cost of the project implementation up to the level of the obligation for each subject via a cost-recovery mechanism financed by a small fixed charge on each liter of fuel sold.

20 Energy saving obligations have the potential to offer a number of advantages over other tried policy tools in the transport sector. Given the ever-increasing importance of transport in environmental and energy security terms, energy saving obligations may be an efficient alternative to taxation. As a baseline-and-credit system, energy saving obligations and TWC schemes work by rewarding projects that improve the efficiency of transportation and deliver savings, rather than based on penalizing consumption the way a tax does.

25 Energy saving obligations and TWCs offer certainty of outcomes ${ }^{21}$, theoretical cost minimization and the possibility for many economic subjects to benefit. The obligation compels economic actors to either directly implement efficiency projects (or energy saving projects) or to buy the certificates from other eligible market

\footnotetext{
${ }^{21}$ Assuming full compliance and no rebound effect
} 
Energy saving obligations and white certificates in transport

actors. Such an arrangement would allow economic parties to certify energy savings and sell certificates without being under an obligation: for instance freight haulage companies may employ efficient solutions (GPS, modal shift, etc.), certify their actions and sell the associated certificates.

The major expected barriers to the introduction of energy saving obligations and TWCs in transportation include

5 high administrative costs especially for the first country introducing this policy portfolio and, more importantly, introducing measurement and verification methodologies to capture actual energy savings, especially for behavioral projects. Administrative costs concern the development of measurement and verification methodologies, cost of administrating and monitoring the scheme, including certificates registry and the market set up if the certificates are tradable. In addition, it may be difficult to establish an appropriate implementing 10 authority: unlike grid bound energies, transport fuels (with the exception of oil markets) are not regulated.

Finally, while a comprehensive comparative review or review of interactions between fuel savings obligations and other tools is outside the scope of the present paper, a few issues need to be emphasized here. First of all, in tackling the demand side of the transport sector, savings targets appear more effective and, more importantly, much more result-oriented than energy taxation due to the low price-elasticity of transport demand. Thus, for a

15 tax to bring genuine savings, it needs to be set a relatively high level, which may politically difficult. In contrast, a small charge of, say, 0.01 Euro/liter of petrol to raise money for the cost recovery of the transportation fuel suppliers would hardly be felt by end-users. If energy saving obligations and TWCs could promote efficient vehicles, they can contribute towards meeting the 2012 target of the European Union of 120 grams $\mathrm{CO}_{2}$ per km relating to the tailpipe emissions of new cars sold. When guaranteeing a certain price for generated TWCs, car manufacturers might even be encouraged to exceed the 2012 target.

As already mentioned, many issues related to the introduction of TWCs are similar to the discussion of $\mathrm{CO}_{2}$ emissions cap-and-trade systems in transport and are mainly based on public acceptability issues (among others) (CE-Delft 2006 and Harwatt 2008). Public acceptability and high transaction and monitoring costs are expected to be key barriers to the implementation of a TWC scheme in the transport.

\section{Conclusions}

This paper marks some initial efforts to explore the possible use of saving obligations and TWCs in the transport sector and to encourage further research on this topic. 


\section{Energy saving obligations and white certificates in transport}

The authors have looked at the importance for sustainable transport policies on the demand side and examined possibilities for setting energy saving obligations on various transport market operators. Types of eligible projects have been discussed, as well as types of market actors eligible to certify project savings without being under an obligation.

5 At this point the authors recommend a system with energy saving obligations imposed on fuel distributors and suppliers above a certain level of annual sales. It is proposed that the system is limited to the transport sector, with only transport projects allowed and with non-obliged actors also eligible to certify savings achieved, such as car manufacturers, public authorities, logistic companies, tyre manufacturers, car hire companies, taxi companies, public transport companies, road haulage companies, and a possible new business - the

10 transportation energy service company - able also to finance a savings package and give energy performance guarantees. The system can have a cost-recovery element, financed by a fund raised by an additional and small charge on fuel sold.

The authors tend to believe that savings obligations and TWCs could achieve better results compared to other transport policies discussed or implemented, such as taxation and $\mathrm{CO}_{2}$ caps. They are also well suited to 15 complement other important policies.

The authors hope that this paper will open a discussion between TWC experts, transport sector professionals and policy makers on the feasibility and advantages of this policy instrument, and on its possible implementation characteristics. The authors see energy saving obligations and TWCs as an additional cost-effective policy instrument that is expected to complement and strengthen existing policy tools in the sector, rather than replace 20 them, with the ultimate aim to reverse the growth in transport energy consumption in the EU. Finally, the authors believe that any further work on the topic should focus on measurement and verification methods for transport efficiency, provide a comparative qualitative evaluation of energy saving obligations and TWCs in the transport sector and other well-established tools (such as taxation), and possibly attempt a quantitative assessment of the scheme, including of the effects from the interactions with other policies. 
Energy saving obligations and white certificates in transport

\section{References}

Anable J. 2008. The cost-effectiveness of carbon abatement in the transport sector, project report, London.

Anable J. 2005. Soft Measures - soft option or smarter choice for early energy savings in the transport sector?, European Council for an Energy Efficient Economy (ECEEE) 2005 Summer Study, Mandelieu, France,

5 30/5/05-4/6/05.

BDI (Federation of German Industries). 2007. Kosten und Potenziale der Vermeidung von Treibhsuagasen in Deutschland, project report, Berlin.

Bertoldi, P., S. Rezessy, E. Lees, P. Baudry, A. Jeandel, and N. Labanca. 2010. Energy supplier obligations and white certificate schemes: Comparative analysis of experiences in the European Union. Energy Policy 38 (3), 1455-1469.

Bertoldi P. and S. Rezessy. 2008. Tradable white certificate schemes: fundamental concepts, Energy efficiency $1(4), 237-255$.

Bertoldi P. and S. Rezessy. 2006. Tradable certificates for energy savings (white certificates): theory and practice, Report published by the European Commission, EUR 22196.

15 BMU (Federal Ministry for the Environment, Nature Conservation, and Nuclear Safety, Germany) (2006), Nationaler Allokationsplan 2008-2012 für die Bundesrepublik Deutschland, Berlin.

Bringezu, S., Schutz, H., O’Brien, M., Kauppi, L., Howarth, R.W. and McNeely, J. (2009) Assessing Biofuels. United Nations Environment Programme, Paris

CE Delft. 2006. Cost effectiveness of $\mathrm{CO}_{2}$ mitigation in transport, project report, Delft.

20 CfIT (Commission for Integrated Transport UK). 2007. Transport and Climate Change, London.

Choo S., P.L. Mokhtarian, and I. Salomon. 2005. Does telecommuting reduce vehicle-miles traveled? An aggregate time series analysis for the U.S, Transportation 32(1), 37-64.

D’haeseleer, W., P. Klees, J.-M. Streydio, R. Belmans-Luc, and J.-M. Chevalier-Wolfgang. 2007. Belgium's Energy Challenges Towards 2030, project report, Commission ENERGY 2030.

25 DeCicco, J. and M. Ross. 1996. Recent Advances in Automotive Technology and the Cost-Effectivenes of Fuel Economy Improvement, Transportation Research D 1(2), 79-96.

DEFRA (Department of Environment, Food and Rural Affairs). 2007. Carbon Emissions Reduction Target April 2008 to March 2011, Consultation Proposals.

EC (European Commission). 2009. Progress Towards Achieving Kyoto Objectives. Report from the Commission to the European Parliament and the Council COM (2009)630 final, SEC (2009)1581. 


\section{Energy saving obligations and white certificates in transport}

EC (European Commission). 2008. EU energy and transport in figures, Statistical pocketbook 2007/2008, DG Energy and Transport, Brussels.

EC (European Commission). 2007. Results of the review of the Community Strategy to reduce $\mathrm{CO}_{2}$ emissions from passenger cars and light-commercial vehicles, $\{\operatorname{SEC}(2007) 60\}$, Communication from the Commission to the Council and the European Parliament.

EC (European Commission). 1995. A community strategy to reduce $\mathrm{CO}_{2}$ emissions from passenger cars and improve fuel economy, Communication from the Commission to the Council and the European Parliament.

European Parliament. 2008. Report on the proposal for a regulation of the European Parliament and of the Council setting emission performance standards for new passenger cars as part of the Community's integrated approach to reduce $\mathrm{CO}_{2}$ emissions from light-duty vehicles, (COM(2007)0856 - C60022/2008 - 2007/0297(COD)), Committee on the Environment, Public Health and Food Safety A60419/2008.

Eurostat. 2009. Eurostat database, www.ec.europa.eu/eurostat.

Eurostat. 2008. Energy and Transport in Figures, Luxemburg.

Eyre, N., M. Pavan and L. Bodineau. 2009. Energy company obligations to save energy in Italy, the UK and France: what have we learned? European Council for Energy Efficiency summer study, La Colle sur Loup, ECEEE.

Friedman B., L. Bird and G. Barbose. 2008. Considerations for emerging markets for energy savings certificates. Washington, Report funded by the Department of Energy, Office of Energy Efficiency and Renewable Energy (EERE).

Frisoni, R. Acceptability of road pricing policies: are tradable permits the only viable alternative? In: 6th Conference on Applied Infrastructure Research "Supply Security and Reliability of European Infrastructure - Efficient Investment, Maintenance, and Operation between Liberalization and Regulation”. Berlin, 5-6 October, 2007.

Frondel M., J. Peters, and C. Vance. 2007. Identifying the Rebound - Theoretical Issues and Empirical Evidence from a German Household Panel. RWI Discussion Paper 57.

Goodwin P., J. Dargay, and M. Hanly. 2004. Elasticities of road traffic and fuel consumption with respect to price and income: a review, Transport Reviews 24(3), 275-292. 
Energy saving obligations and white certificates in transport

Harwatt H. 2008. Reducing carbon emissions from personal road transport through the application of a tradable carbon permit scheme: Empirical findings and policy implications from the UK, Winner of the International Transport Forum Young Researcher Award 2008, Leipzig.

Jochem, P. 2009. A $\mathrm{CO}_{2}$ Emission Trading Scheme for German Road Transport-assessing the impacts using a meso economic model with multi-agent attributes, Baden-Baden.

JRC (2008) Backcasting approach for sustainable mobility Luxembourg, EUR 23387/ISSN 1018-5593, Office for Official Publications of the European Communities.

Larivé J.F., R. Edwards, V. Mahieu, J.C. Griesemann, and D.J. Rickeard. 2004. Well-To-Wheels Analysis of Future Automotive Fuels and Powertrains in the European Context, project report, Sevilla.

10 Monjon, S. 2006. The French Energy Savings Certificates System, ADEME Economics Department.

Oikonomou, V. 2010. Market trading mechanisms for delivering energy efficiency. A report prepared for the Energy Charter Secretariat, available for download at [http://www.encharter.org/index.php?id=483\&L=0]

Oikonomou, V., A. Flamos, , and S. Grafakos. 2010. Is blending of energy and climate policy instruments always desirable?, Energy Policy 38(8), 4186-4195.

OJ (Official Journal of the European Union). 2009. Regulation (EC) No 443/2009 of the European Parliament and of the Council of 23rd April 2009 setting emission performance standards for new passenger cars as part of the Community's integrated approach to reduce $\mathrm{CO} 2$ emissions from light-duty vehicles.

Passey R., I. MacGill, and H. Outhred. 2008. The governance challenge for implementing effective marketbased climate policies: A case study of The New South Wales Greenhouse Gas Reduction Scheme, Energy Policy 36, 3009-3018.

Pavan, M. 2008. Tradable energy efficiency certificates: the Italian experience, Energy Efficiency 1(4), 257-266.

Raux, C. 2004. The use of transferrable permits in transport policy, Transportation research D 9, 185-197.

Raux, C. and G. Marlot. 2004. A system of tradable permits applied to fuel consumption by motorists, Proceedings of the $10^{\text {th }}$ World Conference on Transport Research, Istanbul.

Raux, C. 2010. The potential for $\mathrm{CO}_{2}$ emission trading in transport: the case of personal vehicles and freight, Energy efficiency 3, 133-148.

Rothengatter, W. 2003. How good is first best? Marginal cost and other pricing principles for user charging in transport, Transport Policy 10, 121-130.

30 Schalburg, R. 2009. Chief advisor of the Danish Energy Association, personal communication, 15 June 2009. 


\section{Energy saving obligations and white certificates in transport}

Schäfer, A. 2000. Carbon Dioxide Emissions from World Passenger Transport, Transportation Research Record $1738,20-29$.

Skinner I, van Essen H, Smokers R and Hill N (2010) Towards the decarbonisation of EU's transport sector by 2050 Final report produced under the contract ENV.C.3/SER/2008/0053 between European Commission Directorate-General Environment and AEA Technology plc

Stern N. 2007. Stern review on the economics of climate change, London.

T\&E (Transport and the Environment). 2009. Reducing CO2 emissions from new cars: a study of major car manufacturers' progress in 2008

UKERC (UK Energy Research Centre). 2007. The Rebound Effect: an assessment of the evidence on economy wide energy savings from improved energy efficiency, London.

UBA (Federal Environmental Agency of Germany). 2008. Beschäftigungseffekte des Klimaschutzes in Deutschland, project report, Berlin.

UBA (Federal Environmental Agency of Germany). 2007. $\mathrm{CO}_{2}$-Minderung im Verkehr, project report, Berlin. 